\title{
Article
}

\section{A Review of "Migration and the search for home: mapping domestic space in migrants' everyday lives", By Paolo Boccagni [Book Review]}

Blunt, Caroline

Available at http://clok.uclan.ac.uk/23128/

Blunt, Caroline (2018) A Review of "Migration and the search for home: mapping domestic space in migrants' everyday lives", By Paolo Boccagni [Book Review]. International Journal of Housing Policy, 18 (3). pp. 493-497. ISSN 1949-1255

It is advisable to refer to the publisher's version if you intend to cite from the work. http://dx.doi.org/10.1080/19491247.2018.1467095

For more information about UCLan's research in this area go to http://www.uclan.ac.uk/researchgroups/ and search for <name of research Group>.

For information about Research generally at UCLan please go to http://www.uclan.ac.uk/research/

All outputs in CLoK are protected by Intellectual Property Rights law, including Copyright law. Copyright, IPR and Moral Rights for the works on this site are retained by the individual authors and/or other copyright owners. Terms and conditions for use of this material are defined in the policies page. 
Migration and the Search for Home. Mapping Domestic Space in Migrants' Everyday Lives, by Paolo Boccagni, 2017, Palgrave Macmillan, 136 pp., ISBN 978-1-137-58801-2

This book is intended as an intervention principally in the field of migration studies, but its significance extends to the field of home generally, both as academic field and arena for social intervention. Whilst likened by the author to a 'map', this book does not overly simplify the contours of these fields. Its comprehensive literature review makes it an indispensable resource for academics, policy makers and practitioners. Boccagni's writing style invites response and, with creative use of tables and diagrams, ideas can be compared and applied and this potentially extends its readership beyond the academy. The book's almost 3-dimensional quality is particularly fitting to its subject and it can count as one of the key writings in an emerging multi-disciplinary field in which the question of home has been critically contained, extended and mobilised in relation to its problematic historical valorisation/ stigmatisation. Boccagni contributes to an emerging lexicon with which to theorise home and substantiates the compelling case that 'home' has renewed and contemporary salience.

Acknowledging that 'home' has been 'over-burdened with meanings ...' (p.2) Boccagni makes a convincing argument that it worth unpacking. He characterises home as '[a] special social relationship based on an emplaced (tentative) attribution of security, familiarity and control to one's living circumstances' (p.9). His aim in this book is to challenge the notion that home and migration are antonymic terms. With his emphasis on the social and relational constitution of home, Boccagni helps to cement a growing consensus around a processual as opposed to static understanding. In outlining home's multi-dimensional specificity, Boccagni goes further to make a claim for the value of 'home' as distinct from its apparent synonyms.

Boccagni's social, relational and processual understanding of home leads to an outline of the concept of homing as: 'people's evolving potential to attach a sense of home to their life circumstances, in light of their assets and of the external structure of opportunities' (p.23). Made up of cognitive/ normative (what home is like), emotional (what home feels like) and practice dimensions or labours (how home is made), it is emphasised that homing is an open-ended search and labour (p.27). Acknowledging that homing is present across literary, epic and religious traditions and in recent usage denoting return, destination, deferred arrival or instinct (Brah 2005; Fortier 2001; Ginsberg 1999; Jacobson 2012), Boccagni employs the term in something of a more prosaic sense, referring to a range of spatialised social practices (p.26). If a processual notion of home $=$ home making has largely been accepted within contemporary scholarship (Blunt and Dowling 2006), Boccagni's homing critically casts the search for home as practical, emotional, situated, informed by personal/cultural constructions and affected by a person's access to wider structural resources. The implication of this homing search is a possible gap between the real and the ideal, evoking memory and aspiration in relation to immediate circumstances. Critically, this conceptualisation of homing does not foreclose the possibility of the goal - however unaccomplished - incorporating imaginaries of return and destination.

The book is primarily intended as an intervention in migration studies; a focus on home offers a valuable lens on migrants' everyday lives. The case for a home-migration nexus is made on the basis that 'home matters to the study of migration (and vice versa) (p.19), but moreover, that innovative insights stem from the intersection of these two areas. Boccagni is mainly referring to low-skilled migrants from labour-exporting countries and to a lesser extent, forced migrants and asylum seekers'. Crossing the divide between economic and political migration, a sense of necessity and disadvantage, heightened loss and uncertainty, is implicated. Elsewhere, Boccagni distinguishes this from movements associated with 'salient biographic transition[s]' (p15) which might more easily be captured in the notion of 'housing career'. His claim for the value of a home-migration nexus is based partly upon a particular migrant experience 'from the margins' (p.22) whereby, '[h]ome in the eyes of recently settled migrants and asylum seekers, is often conspicuous by its absence ... In 
practice, it denaturalises [home], as it reveals that the sense of obviousness and familiarity attached to the previous domestic place was ultimately artificial and reversible. Migrants' everyday life, therefore, is a privileged terrain to make sense of home by default' (p.2). As a home-phile whose interests straddle the migrant/ non-migrant divide, it seemed ironic that for a field dealing with movement, migration studies had not contributed more to challenging a sedentarist notion of home; home with-in movement rather than home left and lost. Boccagni's work accentuates need to pay attention to both elements of the staying in the moving and moving in the staying. It is in relation to this latter point that the book has purchase beyond the field of migration. Thus although Boccagni makes a strong claim for the specificity of migrants' experience and theirs as a privileged terrain to make sense of home by default, his work is an intervention in the field of home generally. Within the book, migrants are contrasted with 'sedentary', native or non-migrant counterparts. At the same time, that migrants' home cultures tend to be relatively durable (p.53), 'localised' and consistent" might contrast with non-migrant home cultures in the receiving society where social and cultural change may have been rapid. There may have been an experience of cosmopolitization (Beck 2012), that 'it is often the site that is pulled away from under their feet, so it feels like being on the move anyway' (Bauman 1998:86-87 in Cresswell 2010: 22). Boccagni does alert us to the need to pay attention to the factors that prompted migration in the first place and he describes the relationship between fixed/mobile, static/ dynamic aspects of home as dialectical, therefore not necessarily simply mapping on to the migrant/ non-migrant experience. Where he acknowledges that 'binaries such as native/ immigrant, long settled vs newcomers, sedentary vs mobile and so forth cannot tell the whole story (pxxv), the value of his work to an interrogation of any simple opposition between home as 'stasis' and mobility as 'dynamic' is clear. This might have been further explored in relation to Massey's (1994) notion of 'power geometry', Cresswell's exposition of the politics of (im)mobility (2010), Bauman's (1996) seminal discussion of tourists and vagabonds or the classic tension between Heideggerian/ Deleuzian, monadic/ nomadic notions of home (Brun 2016).

Related to these potentially cross-cutting issues, Boccagni's focus on the migrant experience is enhanced by his attention to 'other axes of diversity', gender, education and life-course in relation to home and homing. Boccagni claims that a defining aspect of migrants' experience of home and homing is a lack of match between life-course biographical transitions and a shift in the temporal and spatial coordinates of home. That home therefore might be a matter of synchrony between these points to the value of Boccagni's work not only for understanding migrants' search for home, but for understanding home across the migrant/ non-migrant divide. Building on other discussions (Hage 2005: 470), this begs further exploration.

In addition to the fields of migration and home, this book might support a more direct intervention across Sociology's divisions of labour in which home has had a particularly contested status (Mallett 2004) and within policy relating to housing, welfare, integration and cohesion. Boccagni notes that home discourse is mobilised across the political spectrum, but unfortunately, it can all too easily be invoked in a sedentarist, exclusionary form. More mutable notions of home are suggested in other terms, such as cohesion, belonging, attachment, but direct discussions of the mutability of home as a public good seem to be rare, left to creative practitioners in less direct roles. 'Home resonates for all of us ...' (pxxv) Boccagni writes, and yet as his book highlights, the resources and opportunities to appoint and accomplish home are riven by deep structural inequalities. These existential, spatial, micro and macro practical, political and politicised concerns and their consequences are effectively articulated in this book. It is for further scholarship to take up Boccagni's explicit invitation and bravely insert this mutable home into research and policy where its conceptual distinctiveness, practical and analytical value, are yet to be realised.

Caroline Blunt School of Humanities and Social Sciences, University of Central Lancashire, Preston, UK 
Email: cblunt1@uclan.ac.uk (C)2018, Caroline Blunt

\section{References}

Beck, U. (2000) The cosmopolitan perspective: sociology of the second age of modernity, in British Journal of Sociology, Vol. 51(1), pp 79-105

Blunt, A. and Dowling, R. (2006) Home. Oxon: Routledge.

Brah, A. (2005) Cartographies of diaspora. London: Routledge

Brun, C. and Fabos, A. (2015) Making homes in limbo? A Conceptual framework, in Refuge, Vol.

31(1), pp 5-18

Brun, C. (2016) Dwelling in the temporary, in Cultural Studies, Vol. 30(3), pp 421-440

Cresswell, T. (2010) Towards a politics of mobility, in Environment and planning D: Society and

Space, Vol. 28, pp 17-31

Fortier, A-M. (2001) 'Coming home' Queer migrations and multiple evocations of home, in Cultural

Studies, Vol. 4(4), pp 405-424

Ginsberg, R. (1999) Meditations on homelessness and being at home. In Abbarno, G. (Ed). (1999) The ethics of homelessness. Amsterdam: Rodopi

Hage, G. (2005) A not so multi-sited ethnography of a not so imagined community, in

Anthropological Theory, Vol. 5(4), pp 463-475

Heller, A. (1995) Where are we at home? In Thesis Eleven, Vol. 41, pp 1-18

Jacobson, K. (2012) Philosophical perspectives on home. In Smith, S. (Ed.) International

Encyclopaedia of Housing and Home. London: Elsevier

Mallett, S. (2004) Understanding home: a critical review of the literature, in The Sociological Review, Vol. 52, pp 62-89 